\title{
EVALUASI EFEKTIVITAS, RELEVANSI, DAN KEBERLANJUTAN DAMPAK PROYEK SECOND WATER SANITATION FOR LOW INCOME COMMUNITIES (WSLIC-2)
}

\author{
Evaluation of Efectivity, Relevancy, And Sustainability on Project Second Water Sanitation For Low \\ Income Communities (WSLIC-2)
}

Rai Sita*) dan Ivanovich Agusta

Departemen Sains Komunikasi dan Pengembangan Masyarakat, Fakultas Ekologi Manusia, IPB

*) E-mail : raisita_kpm43@yahoo.com

Diterima 18 November 2010/Disetujui 4 Februari 2011

\begin{abstract}
The aim of this research are to evaluate how far the Second Water Sanitation for Low Income Communities (WSLIC-2) project appropriate with empowerment concept and to evaluate effectiveness, relevance, and sustainability impact of WSLIC-2 project which implemented in Pangradin village. Empowerment concept that used to analyze WSLIC-2 project design and its implementation in field are 10 principles Community Driven Development (CDD). As a project which based on community, WSLIC-2 project design has appropriated with 10 principles of $C D D$. The principles of $C D D$ which related to concept of plan and construction phase has implemented well in the field. But, the principle who related with concept of maintenances phase not yet implemented well in field. In general, WSLIC-2 project that conducted in Pangradin village assessed quite relevance, but not fully effective and the sustainability is still questionable. Optimization activity of CLTS and strengthening structure of UPS are implementable in order to create a sustainable WSLIC-2 project.
\end{abstract}

Keywords: empowerment, community-driven, and maintenance

\section{PENDAHULUAN}

\section{Latar Belakang}

Air dan sanitasi yang tidak bersih menjadi salah satu akar masalah berbagai penyakit global akibat lingkungan yang berdampak pada kerugian ekonomi. Air bersih dan sanitasi yang tidak memadai menyebabkan sedikitnya 120 juta kasus penyakit dan 50.000 kematian dini setiap tahun di seluruh dunia, dengan dampak ekonomi senilai lebih dari US \$ 3,3 miliar per tahun. Pada tahun 2006, Indonesia kehilangan 2,3 persen produk domestik bruto (Rp. 7,8 triliun) disebabkan oleh sanitasi dan kebersihan air yang tidak memadai. ${ }^{1}$

Salah satu upaya pemerintah dalam meningkatkan akses masyarakat terhadap air bersih dan sanitasi adalah dengan dilaksanakannya proyek Second Water Sanitation for Low Income Communities (WSLIC-2). Proyek WSLIC-2 merupakan bagian dari program pengurangan kemiskinan dan peningkatan kualitas hidup melalui peningkatan akses masyarakat terhadap air bersih dan sanitasi, mengingat akses masyarakat

\footnotetext{
1 Diakses dari

http://www.ird.or.id/index.php?option=com content\&view=article \&id=52\&Itemid =58\&lang=in Pada tanggal 24 November 2009
}

terhadap air bersih dan sanitasi dasar masih sangat rendah. Seiring dengan berkembangnya pendekatan pembangunan di Indonesia, proyek WSLIC-2 pun dilaksanakan menggunakan pendekatan dengan model pemberdayaan masyarakat. Maka, dibutuhkan evaluasi program secara sistematis terhadap aturan normatif dan hasil (outcomes) rill untuk menghasilkan pengetahuan yang lebih mendalam daripada sekedar monitoring, pelaporan, maupun lokakarya tentang hasil program (Agusta, 2002). Evaluasi pun menjadi berharga untuk melihat bagaimana pendekatan dengan model pemberdayaan digunakan dalam pelaksanaan proyek serta sejauhmana kesesuaiannya dalam menghasilkan manfaat dan dampak poyek yang diharapkan hingga menjadi proyek yang berkelanjutan.

\section{Masalah Penelitian}

Pemberdayaan masyarakat difahami sebagai jalan menuju partisipasi masyarakat. Pembangunan dengan pemberdayaan masyarakat adalah sebuah alternatif pembangunan yang merubah proses pembangunan sentralistik menjadi partisipatif (Tohjiwa dan Suparman, 2008). Pembangunan yang dilaksanakan secara partisipatif dengan jalan pemberdayaan diharapkan dapat mengarah pada pembangunan yang berkelanjutan. 
Berdasarkan hal tersebut maka perumusan masalah dalam penelitian ini adalah:

1. Sejauhmana desain proyek WSLIC-2 sejalan dengan konsep pemberdayaan masyarakat?

2. Sejauhmana proyek WSLIC-2 efektif dalam menghasilkan manfaat yang diharapkan?

3. Sejauhmana keluaran proyek WSLIC-2 relevan dengan dampak yang ditimbulkan?

4. Sejauhmana keberlanjutan dampak proyek WSLIC-2 yang diharapkan terwujud?

\section{Tujuan Penelitian}

Berdasarkan permasalah di atas maka, penelitian ini bertujuan untuk:

1. Mengevaluasi kesesuaian desain proyek WSLIC-2 dengan konsep pemberdayaan masyarakat.

2. Mengevaluasi efektivitas proyek WSLIC-2 dalam menghasilkan manfaat yang diharapkan.

3. Mengevaluasi relevansi keluaran proyek WSLIC-2 dengan dampak yang ditimbulkan.

4. Mengevaluasi keberlanjutan dampak proyek WSLIC-2.

Kegunaan Penelitian

Penelitian ini diharapkan dapat bermanfaat, khususnya bagi:

1. Kalangan akademis dapat memberikan kontribusi dan acuan yang integral dalam studi-studi evaluasi pada penelitian evaluasi selanjutnya, khususnya berkaitan dengan proyek pembangunan infrastruktur bidang air bersih dan sanitasi masyarakat.

2. Pelaksana proyek dan institusi terkait dapat memberikan hasil evaluasi yang dapat dijadikan bahan pertimbangan dalam melakukan perbaikan atau pengembangan proyek berikutnya, khususnya pada proyek Program Penyediaan Air Minum dan Sanitasi Berbasis Masyarakat (PAMSIMAS) atau disebut pula dengan WSLIC-3.

\section{PENDEKATAN TEORETIS}

\section{Tinjauan Pustaka}

\section{Evaluasi Proyek}

Konsep evaluasi pembangunan adalah kerja yang direncanakan dan diorganisasikan untuk menilai tujuan pembangunan melalui rencana strategis yang sudah dibuat (Dale, 2001). Sutomo, Hikmat, dan Saragi (2002) mendefinisikan evaluasi sebagai proses penilaian pencapaian tujuan dan pengungkapan masalah kinerja proyek untuk memberikan umpan balik bagi peningkatan kualitas kinerja proyek tersebut. Adapun tujuan evaluasi menurut Sutomo, Hikmat, dan Saragi (2002) adalah untuk mendapatkan informasi dan menarik pelajaran dari pengalaman mengenai pengelolaan proyek (keluaran, manfaat, dan dampak) baik dari proyek yang baru selesai maupun yang sudah berfungsi, sebagai umpan balik bagi pengambilan keputusan untuk perencanaan proyek selanjutnya. Departemen Pertanian (1990) mendefinisikan evaluasi sebagai proses untuk menentukan relevansi, efisiensi, efektivitas dan dampak kegiatan-kegiatan proyek/program sesuai dengan tujuan yang akan dicapai secara sistematik dan objektif.

Menurut Dale (2001) fokus utama evaluasi diilustrasikan oleh hubungan antara variabel inti evaluasi, yaitu evaluasi dampak, efisiensi, efektivitas, relevansi, dan keberlanjutan. Berikut penjelasan mengenai variabel-variabel inti evaluasi tersebut.

1. Efisiensi, didefinisikan sebagai hubungan jumlah dan kualitas output yang dihasilkan dengan sumberdaya yang dikeluarkan. Total biaya output sama dengan jumlah biaya berbagai input yang digunakan untuk menghasilkan output.

2. Efektivitas, menunjukkan sejauh mana output yang direncanakan, efek yang diharapkan, dan dampak yang dimaksudkan dapat tercapai.

3. Relevansi, menilai sejauh mana program atau proyek menempatkan masalah pada prioritas utama, terutama dilihat dari studut pandang stakeholder, khususnya oleh penerima manfaat program/proyek.

4. Dampak, lazimnya bersifat jangka panjang, berupa konsekuensi tidak langsung yang luas dari program/proyek yang dimaksudkan oleh penerima manfaat. Dampak dapat dibedakan menurut dampak positif maupun dampak negatif sesuai dengan sudut pandang penilaianya.

5. Keberlanjutan, merupakan pemeliharaan atau pengaruh tambahan perubahan positif yang dihasilkan oleh program atau proyek sesudah proyek berakhir dilaksanakan. Melalui tindakan keberlanjutan diharapkan program/proyek dapat dilanjutkan meskipun intervensi sudah berakhir, baik oleh organisasi yang sama ataupun oleh organisasi yang berbeda.

\section{Pemberdayaan Masyarakat}

Upaya pembangunan sosial dapat berupa pemberdayaan masyarakat (Adi, 2003). Suatu proses pemberdayaan (empowerment) ditujukan guna membantu klien dalam memperoleh daya untuk mengambil keputusan dan menentukan tindakan yang akan mereka lakukan terkait diri mereka sendiri, termasuk menghilangkan efek hambatan pribadi dan sosial dalam melakukan tindakan tersebut. Hal ini dilakukan melalui peningkatan kemampuan dan rasa percaya diri untuk menggunakan daya yang ia miliki, antara lain melalui transfer daya dari lingkungannya (Payne, 1997 dalam Adi, 2003). Lebih lanjut, Adi (2003) menerangkan inti pemberdayaan adalah bagaimana individu, kelompok, ataupun komunitas berusaha mengontrol kehidupan mereka sendiri dan mengusahakan membentuk masa depan sesuai keinginan mereka.

Perkembangan pendekatan pembangunan di Indonesia dipengaruhi oleh pendekatan pembangunan dari dunia internasional, terutama oleh negara donor. Salah satu pendekatan pembangunan yang menjadi andalan negara-negara berkembang adalah Community Driven Development (CDD). CDD merupakan pendekatan pembangunan produk World Bank yang menempatkan masyarakat miskin dan kelembagaannya sebagai aset dan mitra dalam proses pembangunan. CDD memberikan kontrol keputusan dan sumberdaya di 
tangan kelompok masyarakat. Masyarakat bermitra dengan lembaga penyandang dana, pemerintah setempat, LSM, perusahaan swasta, dan lembaga pemerintah pusat. Pendekatan CDD dilakukan dengan cara penyediaan layanan sosial dan infrastruktur, pengorganisasian aktivitas ekonomi dan manajeman sumberdaya, pemberdayan masyarakat, perbaikan tata pemerintahan, dan peningkatan ketahanan masyarakat miskin (Dongier, et al., 2003).

Dongier, et al. (2003) melanjutkan bahwa untuk mendukung prinsip-prinsip berkelanjutan dan efektivitas proyek pembangunan, CDD memiliki prinsip-prinsip sebagai berikut:

1. Iklim kelembagaan dan kebijakan. Dalam aspek ini dikembangkan iklim yang menunjang pengambilan keputusan oleh komunitas, dalam bentuk pengembangan kebijakan maupun kelembagaan yang sesuai, dan pengembangan hubungan diantara pemerintah.

2. Investasi sesuai kebutuhan. Investasi yang dibutuhkan di sini ialah investasi yang sesuai dengan permintaan komunitas, kalau perlu komunitas dapat turut berinvestasi.

3. Mekanisme partisipasi. Mekanisme ini tertuju pada peningkatan partisipasi warga dan keikutsertaan seluruh stakeholder dalam kegiatan yang sama.

4. Keikutsertaan sesuai gender dan status sosial. Di sini hendak diberi porsi identifikasi yang diikuti dengan partisipasi pihak-pihak yang selama ini termarjinalkan.

5. Investasi pengembangan kapasitas organisasi berbasis masyarakat (CBO). Upaya-upaya pengembangan kemampuan $\mathrm{CBO}$, misalnya melalui pelatihan, dimaknai sebagai investasi yang akan menuai hasil dalam jangka panjang, terutama untuk menciptakan kemandirian.

6. Fasilitasi komunitas untuk informasi. Informasi menjadi penting sebagai input untuk memperoleh hasil keputusan yang sesuai dengan rumusan masalah yang sebenarnya, mencakup informasi tentang proyek, tata cara berhubungan dengan pemerintah dan swasta, serta dengan CBO lainnya, dan informasi untuk hal-hal teknis

7. Aturan sederhana dan insentif/hadiah yang kuat. Aturan yang sederhana memudahkan untuk dilaksanakan, sedangkan insentif memberikan stimulus positif bagi stakeholder untuk melakukannya. Untuk menguatkan hal ini maka dilaksanakan monitoring dan evaluasi.

8. Desain kerja fleksibel. Desain kerja perlu fleksibel sesuai dengan perubahan konteks maupun lingkungan di sekiar kegiatan.

9. Scaling up. Hal ini dilakukan dengan melakukan pengelompokan proyek, diikuti dengan pembentukan jaringan antar CBO.
10. Exit strategy. Upaya perumusan exit strategy untuk mempersiapkan kemandirian menjadi penting sebagai perwujudan perencanaan yang rasional.

Sebagai pendekatan yang menekankan pada pengembangan kapasitas institusi lokal, CDD menetapkan alternatif kelembagaan sebagai berikut: (Dongier, et al., 2003)

1. Hubungan antara $\mathrm{CBO}$ dengan pemerintah setempat atau yang dipilih

2. Hubungan antara CBO dengan LSM atau swasta

3. Hubungan langsung $\mathrm{CBO}$ degan pemerintah pusat atau lembaga donor pusat

Uphoff (1986) menyatakan bahwa dalam proses implementasi pembangunan infrastruktur desa, upaya untuk memantapkan infrastruktur harus dilakukan bersamaan dengan menciptakan atau menguatkan institusi lokal untuk membangun dan memelihara infrastruktur. Pengetahuan lokal dan sumberdaya lokal sangat dibutuhkan pada fase mendesain dan kontruksi proyek, sama seperti halnya input lokal dan komitmen yang dibutuhkan untuk pengoperasian dan pemeliharaan.

\section{Deskripsi Proyek}

Second Water and Sanitation for Low Income Community (WSLIC-2) adalah proyek air bersih dan sanitasi untuk masyarakat berpenghasilan rendah. Proyek WSLIC-2 dijalankan oleh Kementerian Kesehatan dibantu oleh Kementrian Dalam Negeri, Kementrian Pekerjaan Umum, dan Kementrian Pendidikan Republik Indonesia. Selain mencirikan sebagai proyek yang berhubungan langsung dengan pengembangan masyarakat, hasil laporan LP3ES tahun 2003 menyebutkan proyek WSLIC-2 juga merupakan proyek yang menghabiskan dana cukup besar, mencapai US \$ 106,7 juta dengan target sampai ke kecamatan dan pedesaan. Sumber dana proyek berasal dari pinjaman World Bank (International Development Association/IDA Credit), Hibah AusAID, pendampingan pemerintah yang bersumber dari Anggaran Pendapatan dan Belanja Negara (APBN) dan Anggaran Pendapatan dan Belanja Daerah (APBD), serta kontribusi masyarakat. Kegiatan WSLIC-2 diselenggarakan di delapan provinsi yang terdiri dari 36 kabupaten dan 2.461 desa. Proyek WSLIC-2 memiliki tujuan untuk meningkatkan status kesehatan, produktivitas dan kualitas hidup masyarakat yang berpenghasilan rendah di pedesaan, melalui :

a. Perbaikan perilaku hidup bersih dan sehat.

b. Peningkatan pelayanan kesehatan masyarakat.

c. Penyediaan fasilitas air bersih dan sanitasi melalui pemberdayaan masyarakat.

d. Kesinambungan pemberdayaan masyarakat secara partisipatif.

Adapun komponen kegiatan WSLIC-2 adalah:

a. Peningkatan kapasitas masyarakat dan institusi daerah. 
b. Peningkatan perilaku hidup bersih dan sehat serta pelayanan kesehatan masyarakat.

c. Pembangunan dan pemeliharaan sarana air bersih dan sanitasi.

\section{d. Manajemen kegiatan.}

\section{Kerangka Pemikiran}

Kerangka pemikirian penelitian ini mengacu kepada prinsip evaluasi sebagaimana dikemukakan oleh Dale (2001). Penelitian dilakukan pertama kali dengan menganalisis desain proyek WSLIC-2 dengan menggunakan konsep sepuluh prinsip CDD sebagai titik tolak dalam menilai peluang keberlanjutan dan efektivitas CDD. Kesepuluh prinsip tersebut adalah: iklim kelembagaan dan kebijakan, investasi sesuai kebutuhan, mekanisme partisipasi, keikutsertaan sesuai gender dan status sosial, investasi pengembangan kapasitas CBO, fasilitas informasi, aturan sederhana dan insentif, desain kerja fleksibel, scaling up, dan exit strategy. Analisis ini dilakukan untuk melihat sejauhmana desain proyek WSLIC-2 sejalan dengan konsep pemberdayaan masyarakat tersebut. Desain proyek yang dilihat mencakup tujuan proyek, organisasi pelaksana proyek, dan lingkungan proyek. Organisasi pelaksana proyek meliputi Tim Kerja Masyarakat (TKM) dan Unit Pengelola Sarana (UPS) sebagai organisasi berbasis masyarakat yang merupakan pelaksana proyek di tingkat Desa. Sementara itu, lingkungan proyek merupakan pemerintah kecamatan, pemerintah kabupaten, dan pemerintah provinsi, serta International Development Association (IDA) World Bank dan AusAID sebagai lembaga donor yang memberikan dana pinjaman terhadap proyek tersebut.

Kemudian struktur tujuan disusun berdasarkan desain proyek yang sudah dirancang mulai dari keluaran, manfaat ${ }^{2}$, hingga kepada dampak proyek WSLIC-2 untuk dilihat sejauh mana pencapaiannya di lapangan. Dampak proyek WSLIC-2 merupakan tujuan umum dari pelaksanaan program yaitu meningkatkan status kesehatan, poduktivitas, dan kualitas hidup masyarakat miskin di pedesaan. Manfaat merupakan tujuan khusus pelaksanaan proyek WSLIC-2, yaitu peningkatan pelayanan kesehatan masyarakat, pemeliharaan sarana air bersih dan sanitasi, perbaikan perilaku hidup bersih dan sehat, dan kesinambungan pemberdayaan masyarakat secara partisipatif. Keluaran merupakan hasil langsung dari pelaksanaan komponen-komponen proyek WSLIC-2, yaitu pengembangan kapasitas masyarakat dan institusi daerah, adanya manajemen kegiatan, penyediaan sarana air bersih dan sanitasi, dan kecenderungan perubahan perilaku menuju hidup bersih dan sehat.

Pencapaian tujuan proyek WSLIC-2 dipengaruhi oleh faktor eksternal. Faktor eksternal yang berpengaruh terhadap dampak adalah adanya malnutrisi ataupun penyakit yang ditimbulkan di luar dari masalah air bersih dan sanitasi yang rendah. Hal tersebut dapat menurunkan dampak proyek yang diharapkan. Faktor eksternal manfaat meliputi kualitas bahan yang

${ }^{2}$ Penulis mengasumsikan manfaat proyek sama dengan efek proyek

$220 \mid$ Raisita. et. al. Evaluasi Efektivitas, Relevansi, dan Keberlanjutan Dampak Proyek WSLIC-2 digunakan dalam kontruksi sarana air bersih dan sanitasi. Meskipun masyarakat memiliki kemampuan, kemauan, serta kesempatan dalam memelihara dan mengelola sarana air bersih dan sanitasi, sarana tersebut mudah rusak jika bahan yang digunakan dalam kontruksi sarana air bersih dan sanitasi memiliki kualitas rendah sehingga fungsi infrastruktur tidak bertahan lama. Faktor eksternal yang mempengaruhi keluaran adalah kesempatan dan kemauan masyarakat untuk berpartisipasi dalam keseluruhan proses pelaksanaan proyek WSLIC-2. Kesempatan merupakan waktu yang dimiliki masyarakat untuk berpartisipasi, sementara itu kemauan merupakan kesadaran masyarakat tentang pentingnya berpartisipasi dalam kegiatan pembangunan desa.Keluaran, manfaat, dan dampak kemudian dianalisis lebih lanjut untuk melihat efektivitas, relevansi, dan keberlanjutan dampak proyek WSLIC-2 yang diharapkan. Sesuai dengan perspektif evaluasi sebagaimana dikemukakan oleh Dale (2001) efektivitas dilihat melalui sejauh mana keluaran, manfaat, dan dampak proyek WSLIC-2 dapat tercapai sesuai dengan tujuan awal yang telah dirancang. Relevansi ditentukan dengan melihat sejauh mana keluaran, manfaat, dan dampak proyek WSLIC-2 benarbenar menjawab kebutuhan masyarakat. Keberlanjutan dapat ditentukan dengan melihat sejauh mana keberadaan dampak dan pemeliharaan hasil proyek-2 dapat berkelanjutan pasca proyek berakhir hingga penelitian ini dilaksanakan. Susunan kerangka pemikiran disajikan pada Gambar 1.

\section{Hipotesis}

Pada penelitian evaluasi ini, hipotesis disusun untuk menguji signifikansi perubahan aspek-aspek keluaran, manfaat, dan dampak poyek WSLIC-2, khususnya perubahan pada perilaku hidup bersih masyarakat. Hipotesis uji meliputi:

1. Terdapat perubahan kecenderungan masyarakat yang signifikan terhadap perilaku hidup bersih antara sebelum dan sesudah pelaksanaan proyek WSLIC-2.

2. Terdapat perubahan perilaku masyarakat yang signifikan terhadap hidup bersih antara sebelum dan sesudah pelaksanaan proyek WSLIC-2.

3. Terdapat peningkatan status kesehatan yang signifikan pada masyarakat antara sebelum dan sesudah pelaksanaan proyek WSLIC-2.

4. Terdapat peningkatan produktivitas masyarakat yang signifikan antara sebelum dan sesudah pelaksanaan proyek WSLIC-2.

5. Terdapat peningkatan kualitas hidup masyarakat yang signifikan antara sebelum dan sesudah pelaksanaan proyek WSLIC-2.

6. Terdapat peningkatan akses masyarakat yang signifikan terhadap air bersih antara sebelum dan sesudah pelaksanaan proyek WSLIC-2.

7. Terdapat peningkatan akses masyarakat yang signifikan terhadap sanitasi antara sebelum dan sesudah pelaksanaan proyek WSLIC-2.

8. Terdapat peningkatan akses siswa SD yang signifikan terhadap sanitasi antara sebelum dan sesudah pelaksanaan proyek WSLIC-2. 
9. Terdapat penurunan tingkat kesulitan akses yang signifikan terhadap air bersih antara sebelum dan sesudah pelaksanaan proyek WSLIC-2.

10. Terdapat tingkat pemanfaatan yang signifikan terhadap sarana air bersih WSLIC-2.

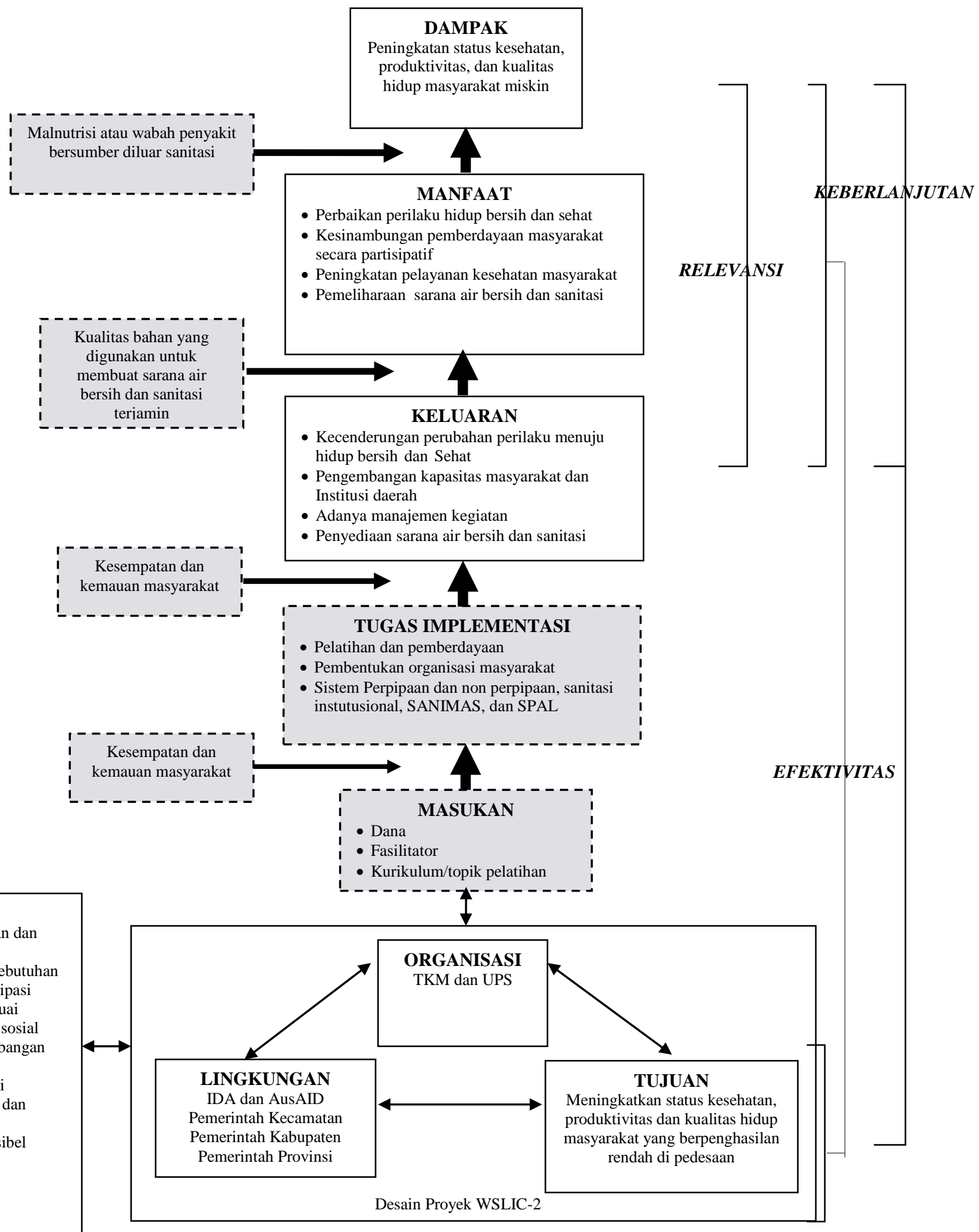

Gambar 1. Kerangka Pemikiran Penelitian 
Keterangan

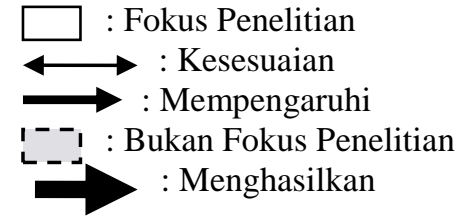

\section{PENDEKATAN LAPANGAN \\ Metode Penelitian}

Penelitian ini dilakukan dengan menggunakan campuran dua metode, yaitu metode kualitatif dan metode kuantitatif. Metode kualitatif digunakan untuk mengetahui kesejajaran desain proyek WSLIC-2 dengan konsep pemberdayaan masyarakat dengan cara analisis dokumen mengenai desain WSLIC-2 yang sudah dirancang oleh penyelenggara proyek kemudian membandingkannya dengan konsep pemberdayaan. Kesejajaran proyek WSLIC-2 dengan konsep pemberdayaan masyarakat juga diperkaya dengan menganalisis implementasi proyek di lapangan melalui metode wawancara mendalam. Pendekatan kuantitatif digunakan untuk mengetahui keluaran, manfaat, dan dampak proyek WSLIC-2 dengan menggunakan kuesioner yang diperkaya pula dengan data kualitatif melalui wawancara mendalam. Setelah mengetahui desain, keluaran, manfaat, dan dampak proyek, maka analisis lebih lanjut dapat dilakukan untuk melihat efektivitas, relevansi, dan keberlanjutan dampak proyek WSLIC-2.

\section{Lokasi dan Waktu Penelitian}

Penelitian dilaksanakan pada bulan Maret hingga Mei 2010. Penelitian ini dilaksanakan di Desa Pangradin, Kecamatan Jasinga, Kabupaten Bogor, Provinsi Jawa Barat. Lokasi penelitian dipilih dengan pertimbangan Desa Pangradin merupakan salah satu desa lokasi pelaksana proyek WSLIC-2 yang dipandang berhasil oleh para stakeholder proyek WSLIC-2 karena salah satu tujuan penelitian ini adalah untuk mengevaluasi keberlanjutan. Pertimbangan keberhasilan proyek WSLIC-2 di Desa Pangradin tersebut lebih memungkinkan peneliti dalam melakukan evaluasi terhadap efektivitas dan relevansi, terutama evaluasi mengenai keberlanjutan proyek karena sekalipun proyek dipandang berhasil namun belum menjamin adanya suatu keberlanjutan.

\section{Teknik Pengumpulan Data}

Data kualitatif didapatkan melalui analisis dokumen yang berkaitan dengan proyek WSLIC-2 serta melalui metode wawancara mendalam terhadap anggota TKM, Anggota Tim Kordinasi Kecamatan (TKKc) dan anggota Unit Pengelola Sarana (UPS). Informan diambil secara purposif. Data kuantitatif didapat melalui survai terhadap anggota rumahtangga di Desa Pangradin. Responden diambil dengan menggunkan pendekatan sampel acak terstratifikasi (stratified random sampling). Populasi dibagi ke dalam subpopulasi berdasarkan klasifikasi kesejahteraan sehingga satuan elementer dalam masing-masing subpopulasi menjadi homogen dan setiap anggota populasi memiliki probabilitas yang sama pada setiap strata yang berbeda. Selain itu, berdasarkan tujuan analisis, teknik penarikan sampel menggunakan pendekatan sampel acak terstratifikasi berdasarkan kesejahteraan sengaja dipilih agar dapat melakukan analisis perbandingan antara rumahtangga mampu dan rumahtangga tidak mampu karena sasaran sebenarnya proyek adalah masyarakat berpenghasilan rendah (low income). Adapun, penentuan jumlah sampel atau responden ditentukan berdasarkan hasil perhitungan menggunakan rumus Slovin sebagai berikut (Consuelo, 1993 dalam Prasetyo dan Jannah, 2006):

$$
\mathrm{n}=\frac{N}{1+N \mathrm{e}^{2}}
$$

Keterangan:

$$
\begin{array}{ll}
\mathrm{n} & \text { : jumlah sampel } \\
\mathrm{N} & \text { : jumlah populasi } \\
\mathrm{e} & \text { : nilai kritis (batas ketelitian) yang digunakan } \\
\text { (10 persen) }
\end{array}
$$

Berdasarkan data yang terdapat pada Rencana Kerja Masyarakat (RKM) proyek WSLIC-2 Desa Pangradin, jumlah rumah tangga berdasarkan tingkat kesejahteraan terdiri dari rumahtangga mampu berjumlah 440 rumahtangga $(40,14$ persen) dan rumahtangga tidak mampu berjumlah 656 rumahtangga $(59,86 \text { persen })^{3}$. Berdasarkan rumus Slovin, dengan nilai kritis 10 persen (0.1) jumlah responden yang perlu diambil minimal 82 rumahtangga mampu dan sebanyak 86 rumahtangga tidak mampu. Penentuan responden dilakukan dengan menggunkan tabel angka acak.

Survai juga dilakukan terhadap anggota TKM sekaligus anggota Unit Pengelola Sarana (UPS) dan siswa Sekolah Dasar (SD) yang ada di Desa Pangradin. Responden dari TKM, UPS, dan siswa SD diambil dengan menggunkan pendekatan sampel acak sederhana (simple random sampling). Sesuai dengan rumus Slovin, jumlah responden yang diambil dari anggota TKM dan UPS sebanyak sembilan orang dari 10 orang populasi. Siswa yang diambil sebagai responden adalah siswa kelas V SD Pangradin II dengan jumlah populasi sebanyak 46 orang dan siswa kelas VI dan V SD Pangradin IV dengan jumlah populasi sebanyak 28 dan 17 orang sehingga sesuai dengan rumus Slovin jumlah siswa yang diambil sebagai responden sebanyak 67 siswa. Responden siswa SD diambil secara acak menggunakan tabel angka acak.

\section{Teknik Analisis Data}

Analisis terhadap dokumen dilakukan dengan metode kualitatif dan semiotif. Dalam hal ini konsep tertulis dalam aturan main dibandingkan dengan konsep umum untuk pembangunan yang partisipatif (Sachs, 1992 dalam Agusta, 2002). Seluruh data kualitaif termasuk data hasil wawancara mendalam dengan responden dianalisis menurut hubungannya dengan tema-tema pemberdayaan. Melalui perbandingan hasil analisis data tersebut dapat diperoleh kesimpulan dan teori yang

\footnotetext{
Data diambil dari RKM Proyek WSLIC-2 Desa Pangradin yang merupakan hasil pemetaan sosial dan tolok ukur klasifikasi berdasarkana pada jumlah pendapatan per kapita masyarakat, kondisi rumah, serta kepemilikan harta benda.
} 222 Raisita. et. al. Evaluasi Efektivitas, Relevansi, dan Keberlanjutan Dampak Proyek WSLIC-2 
dapat diwujudkan dalam suatu diagram teoritis (Agusta, 2002).

Analisis terhadap data kuantitatif dilakukan melalui program komputer kuantitatif SPSS 13.0. Teknik analisis data menggunakan tabel frekuensi, penyajian grafik, dan uji statistik dengan prosedur pengujian data baik menggunakan statistika non paramterik maupun parametrik. Mengingat jenis sampel pada penelitian ini merupakan sampel yang berhubungan (tidak saling bebas) maka uji non parametrik yang digunakan adalah uji dua sampel berhubungan (two sample related test) untuk uji rangking bertanda Wilcoxon dan uji Mc Nemar. Kedua jenis uji tersebut sengaja dipilih karena dianggap paling tepat dalam menguji hasil data yang dipilih berdasarkan pada tujuan analisis dan skala pengukuran yang digunakan.

Uji Mc Nemar digunakan untuk mengukur signifikansi perubahan perilaku hidup bersih serta perilaku sanitasi sehat untuk data-data dengan skala pengukuran nominal atau ordinal. Uji rangking bertanda Wilcoxon digunakan untuk mengukur siginifikansi perubahan untuk data-data dengan skala pengukuran ordinal atau interval. Siginifikansi perubahan yang diukur antara sebelum dan sesudah pelaksanaan proyek WSLIC-2 dilakukan terhadap setiap responden. Sehingga setiap responden diperlakukan sebagai dua sampel yang berhubungan. Adapun, statistika parametrik yang digunakan adalah uji $\mathrm{T}$ berpasangan. Statistik uji $\mathrm{T}$ berpasangan dilakukan untuk menguji sejauh mana perbedaan rata-rata pendapatan masyarakat antara sebelum dan sesudah pelaksanaan proyek WSLIC2.

Hipotesis uji pada statistik uji Mc Nemar dan uji rangking bertanda Wilcoxon adalah menguji signifikansi perubahan yang memberikan kesimpulan apakah perubahan tersebut signifikan atau tidak. Kaidah keputusan menggunakan nila alpha 5 persen. Karena menggunakan uji dua sisi (two tiled) maka keputusan diambil dengan membandingkan p-value dengan alpha dibagi dua. Jika p-value kurang dari alpha dibagi dua (0.25) maka keputusan yang diambil adalah tolak $\mathrm{Ho}^{4}$. Untuk uji $\mathrm{T}$ berpasangan kaidah keputusan menolak Ho jika p-valeu kurang dari alpha dibagi dua.

\section{GAMBARAN UMUM DESA PANGRADIN}

\section{Kondisi Geografis}

Pangradin merupakan salah satu dari enam belas desa yang terletak di Kecamatan Jasinga. Kabupaten Bogor, Provinsi Jawa Barat. Desa Pangradin berjarak $63 \mathrm{~km}$ dari ibu kota Jakarta, $124 \mathrm{~km}$ dari ibu kota provinsi, 31 $\mathrm{km}$ dari ibu kota kabupaten, dan $8 \mathrm{~km}$ dari Kecamatan Jasinga. Desa Pangradin terletak pada ketinggian 250 mdpl dan memiliki curah hujan $1500 \mathrm{~mm} /$ tahun dengan suhu terendah $23^{\circ} \mathrm{C}$ dan suhu tertinggi $32^{\circ} \mathrm{C}$.

\footnotetext{
${ }^{4}$ Ho (Hipotesa Nol) : Hipotesa yang menunjukkan tidak ada perubahan (pada sejumlah variabel yang diukur) antara sebelum dan sesudah pelaksanaan proyek WSLIC-2. Pada pengujian statistik, umunya keputusan yang diharapkan adalah tolak Ho.
}

Desa Pangradin memiliki luas keseluruhan sebesar 1.175 ha dengan luas perkebunan sebesar 791 ha, luas sawah 320 ha, luas kolam 12 ha, dan luas pemukiman penduduk 52 ha. Akses Desa Pangradin menuju kota kecamatan dihubungkan oleh jalan raya yang melewati kebun dan sawah milik masyarakat. Masyarakat menggunakan sarana transportasi ojeg untuk menuju wilayah kota kecamatan.

Secara administratif, Desa Pangradin terbagi ke dalam dua dusun, yakni Dusun Pangradin 1 dan Dusun Pangradin 2. Keseluruhan dusun terbagi ke dalam 6 Rukun Warga (RW) dan 30 Rukun Tetangga (RT). Sebelah Utara Desa Pangradin berbatasan dengan Desa Sipak, sebelah Selatan berbatasan dengan Taman Nasional Gunung Halimun Salak, sebelah Barat berbatasan dengan Desa Jugala Jaya, dan sebelah Timur berbatasan dengan Desa Kalong Sawah.

\section{Kondisi Ekonomi}

Desa Pangradin tergolong ke dalam desa tertinggal, sehingga memenuhi syarat untuk terpilih sebagai lokasi pelaksana proyek WSLIC-2. Sebagian besar penduduk Desa Pangradin bermata pencaharian sebagai petani, petani penggarap dan buruh tani dengan pendapatan yang tidak tetap. Penduduk Desa Pangradin memiliki jumlah angkatan kerja sebanyak 1.475 orang yang mayoritas bekerja sebagai buruh tani (39,32 persen).

Selain menanam padi, kegiatan pertanian juga berupa penanaman pohon albasia (Paraseriarenthes falkatharia), manggis, durian, petai, cempedak, dan tanaman buah lainnya. Jenis palawija yang ditanam meliputi singkong, pisang, jagung, dan lain-lain. Tingkat pendapatan masyarakat meningkat ketika masa panen tiba, terutama masa panen buah manggis dan buah durian. Masa panen paling cepat satu kali per tahun. Para petani mengutamakan penggunaan hasil pertanian untuk konsumsi pribadi, dan setelah masih ada sisa barulah dijual kepada tengkulak atau dijual langsung di pasar. Lahan di Desa Pangradin tergolong subur, baik untuk kegiatan pertanian maupun perkebunan. Lahan seluas 76 ha merupakan lahan eks tanah HGU (Hak Guna Usaha) yang telah puluhan tahun dimanfaatkan sebagai lahan perkebunan karet. Tahun 2008 lahan tersebut dibebaskan untuk dijadikan hak milik warga Desa Pangradin. Lahan perkebunan dikonversi oleh warga untuk penanaman albasia dan palawija. Pembagian lahan tersebut menjadikan masyarakat lebih produktif, meskipun beberapa warga telah menjual lahan hak miliknya kepada orang lain akibat kesulitan ekonomi.

Desa Pangradin juga memiliki potensi sebagai desa wisata. Di sini terdapat Taman Wisata Curug Bandung yang merupakan bagian dari Taman Nasional Gunung Halimun-Salak (TNGHS). Taman Wisata Curug Bandung telah direncanakan akan dibangun pada tahun 2010. Walaupun hingga saat penelitian berlangsung obyek wisata alam tersebut belum ditata dan belum resmi penggunaannya, akan tetapi sudah banyak para wisatawan yang datang dari Tangerang dan Jakarta. Potensi sumber daya air yang melimpah yang bersumber dari mata air pegunungan dalam kawasan 
TNGHS tersebut kini telah dimanfaatkan oleh warga sebagai sumber air bersih dalam program pembangunan sarana air bersih WSLIC-2.

\section{Kondisi Sosial}

Desa Pangradin memiliki jumlah penduduk sebanyak 5.750 jiwa, terdiri dari 2.955 laki-laki dan 2.795 perempuan. Jumlah kepala keluarga (KK) mencapai 1.392 KK. Berdasarkan tingkat kesejahteraan ekonomi, rumah tangga miskin memiliki proporsi lebih tinggi dibandingkan jenis rumah tangga lainnya. Bahkan terdapat beberapa rumahtangga miskin yang tinggal dalam satu rumah. Data hasil pemetaan desa pada tahun 2008 (Tabel 1) menunjukkan klasifikasi tingkat kesejahteraan masyarakat tersebut.

Tabel 1. Jumlah Penduduk, Rumah Tangga, dan Rumah Menurut Tingkat Kesejahteraan di Desa Pangradin, Tahun 2008

\begin{tabular}{|l|r|r|r|r|r|r|}
\hline \multirow{2}{*}{ Uraian } & \multicolumn{2}{|c|}{$\begin{array}{c}\text { Jumlah } \\
\text { Penduduk }\end{array}$} & \multicolumn{2}{|c|}{ Jumlah KK } & \multicolumn{2}{c|}{$\begin{array}{c}\text { Jumlah } \\
\text { Rumah }\end{array}$} \\
\cline { 2 - 7 } & $\begin{array}{c}\text { Jum } \\
\text { lah }\end{array}$ & $\begin{array}{c}\text { Persen } \\
\text { tase }\end{array}$ & $\begin{array}{c}\text { Jum } \\
\text { lah }\end{array}$ & $\begin{array}{c}\text { Persen } \\
\text { tase }\end{array}$ & $\begin{array}{c}\text { Jum } \\
\text { lah }\end{array}$ & $\begin{array}{c}\text { Perse } \\
\text { ntase }\end{array}$ \\
\hline Kaya & 231 & 04,02 & 125 & 08,98 & 44 & 04,0 \\
$\%$ & & & $\begin{array}{r}0 \\
1 \%\end{array}$ \\
\hline Menen & 2.08 & 36,14 & 363 & 26,08 & 396 & 36,1 \\
gah & 7 & $\%$ & & $\%$ & & $3 \%$ \\
\hline Miskin & 3.44 & 59,84 & 904 & 64,94 & 656 & 59,8 \\
& 1 & $\%$ & & $\%$ & & $6 \%$ \\
\hline Jumlah & 5.75 & 100,0 & 1.3 & 100,0 & 1.09 & 100 \\
& 0 & $0 \%$ & 92 & $0 \%$ & 6 & $00 \%$ \\
\hline
\end{tabular}

Sumber : Diolah dari hasil pemetaan sosial RKM

WSLIC-2 tahun 2008

Tolok ukur klasifikasi menurut tingkat kesejahteraan di atas didasarkan pada pendapatan perkapita masyarakat, kondisi rumah, serta kepemilikan harta benda. Berdasarkan Tabel 1 di atas, diketahui sekitar 60 persen penduduk Desa Pangradin masih berada di bawah garis kemiskinan.

Kualitas hidup masyarakat tak hanya dilihat berdasarkan tingkat kesejahteraan, akan tetapi juga dilihat dari tingkat pendidikan dan derajat kesehatan. Tingkat pendidikan masyarakat Desa Pangradin tergolong sangat rendah. Hanya sedikit pelajar (0,38 persen) yang melanjutkan pendidikan hingga pendidikan menengah. Banyak pula pelajar yang tidak dapat melanjutkan pendidikan ke jenjang SMP baik karena alasan ekonomi maupun kesadaran untuk melanjutkan pendidikan.

Derajat kesehatan menjadi salah satu tolok ukur untuk melihat kualitas hidup masyarakat. Salah satu elemen penting dalam menunjang kesehatan masyarakat adalah akses terhadap air bersih dan sanitasi dasar. Sebelum adanya proyek WSLIC-2, akses masyarakat Desa Pangradin terhadap air bersih dan sanitasi masih sangat rendah baik untuk masyarkat miskin, menengah, maupun kaya. Persentase keseluruhan masyarakat yang memiliki akses terhadap air bersih hanya mencapai 8,94 persen dari jumlah rumah yang terdapat di Desa Pangradin. Semua jenis rumah, baik dari kategori miskin, sedang, maupun kaya memiliki akses yang masih sangat rendah terhadap air bersih dengan persentase tertinggi sebesar 43,18 persen. Sementara itu, persentase total akses masyarakat terhadap sanitasi (jamban) hanya mencapai 38,41 persen. Meskipun lebih baik dari akses terhadap air bersih namun tetap saja jumlah masyarakat yang memiliki akses terhadap sanitasi terbilang masih sangat rendah, terutama untuk kategori rumah miskin.

Lokasi rumah-rumah masyarakat yang dekat dengan sungai membuat masyarakat terbiasa menggunakan air sungai untuk kebutuhan hidup sehari-hari dan terbiasa pula untuk BAB (Buang Air Besar) di sungai. Air sungai yang berasal dari pegunungan di kawasan TNGHS ini banyak melintasi perkampungan yang jaraknya tidak jauh dari rumah-rumah penduduk. Hanya sedikit rumahtangga yang belum memiliki sumur gali dan jamban, dan rumahtangga tersebut masih menggunakan air sungai untuk mencuci, mandi dan BAB. Hal ini terjadi terutama pada musim kemarau, ketika masyarakat kesulitan mendapatkan air karena sungai dan sumur mengering. Hal ini tentu saja dapat memicu timbulnya berbagai gangguan kesehatan bagi masyarakat sehingga derajat kesehatan masyarakat menjadi sangat rendah. Sebenarnya masyarakat memiliki potensi sumber air yang melimpah di pegunungan dalam kawasan TNGHS yang tidak akan kering meski musim kemarau tiba. Oleh karena itu, adanya proyek WSLIC-2 ini telah mendekatkan masyarakat pada sumber air tersebut sehingga menambah jumlah masyarakat yang memiliki akses terhadap air bersih dan tidak kesulitan lagi untuk mendapatakan air meskipun musim kemarau tiba.

\section{HASIL PENELITIAN}

\section{Analisis Desain Proyek WSLIC-2}

Konsep CDD (community-driven development) memiliki sepuluh ciri, yaitu iklim kelembagaan dan kebijakan, investasi sesuai kebutuhan, mekanisme partisipasi, keikutsertaan sesuai gender dan status sosial, investasi pengembangan kapasitas organisasi berbasis masyarakat, fasilitas informasi untuk komunitas, aturan sederhana dan insentif/hadiah yang kuat, desain kerja fleksibel, scaling up, dan exit strategy. Analisis desain Proyek WSLIC-2 dilaksanakan dengan membandingkan antara tata aturan dalam WSLIC-2 dan kesepuluh ciri CDD. Pada saat diperlukan, analisis juga mencakup kasus-kasus di lapangan. Berdasarkan hasil analisis terhadap dokumen WSLIC-2 10 ciri CDD telah termuat dalam desain WSLIC-2, terutama untuk ciri pertama hingga ciri kedelapan. Namun untuk desain ciri kesembilan dan sepuluh, yaitu scaling up dan exit strategy belum termuat secara jelas dalam desain. Hal tersebut tampaknya berpengaruh terhadap impelementasi proyek di lapangan pada fase pemeliharaan. Berikut hasil analisis desain dan implementasi proyek WSLIC-2 terhadap 10 ciri CDD yang disajikan pada Tabel 2. 
Tabel 2. Ringkasan Hasil Analisis Desain dan Implementasi Proyek WSLIC-2 Berdasarkan 10 Prinsip CDD

\begin{tabular}{|c|c|c|c|}
\hline $\begin{array}{l}\mathbf{N} \\
\mathbf{0} .\end{array}$ & $\begin{array}{l}10 \text { Prinsip } \\
\text { CDD }\end{array}$ & $\begin{array}{l}\text { Desain Proyek } \\
\text { WSLIC-2 }\end{array}$ & $\begin{array}{l}\text { Implementasi } \\
\text { Proyek WSLIC-2 }\end{array}$ \\
\hline 1. & $\begin{array}{l}\text { Iklim } \\
\text { kelembagaan } \\
\text { dan } \\
\text { kebijakan }\end{array}$ & 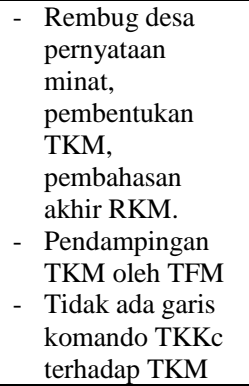 & $\begin{array}{l}\text { - Rembug desa } \\
\text { pernyataan minat, } \\
\text { pembentukan } \\
\text { TKM, } \\
\text { pembahasan akhiı } \\
\text { RKM. } \\
\text { - Pendampingan } \\
\text { TKM } \\
\text { - Tidak ada } \\
\text { intervensi TKKc } \\
\text { terhadap TKM }\end{array}$ \\
\hline 2. & $\begin{array}{l}\text { Investasi } \\
\text { sesuai } \\
\text { kebutuhan }\end{array}$ & $\begin{array}{l}\text { - Kriteria } \\
\text { pemilihan lokasi } \\
\text { - Pilihan } \\
\text { komponen } \\
\text { kegiatan } \\
\text { berdasarkan } \\
\text { demand- } \\
\text { responsive } \\
\text { - Dilaksankan } \\
\text { setelah ada } \\
\text { pernyataan minat } \\
\text { masyarkat } \\
\end{array}$ & 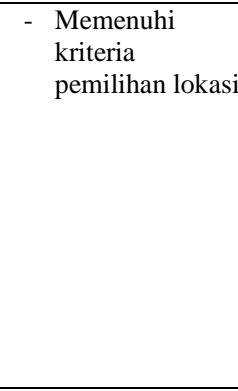 \\
\hline 3. & $\begin{array}{l}\text { Mekanisme } \\
\text { partisipasi }\end{array}$ & $\begin{array}{ll}\text { - } & \text { Identifikasi dan } \\
\text { analisa situasi } \\
\text { - } & \text { Rembug desa } \\
\text { - } & \text { Penyusunan } \\
& \text { RKM } \\
\text { - } & \text { Kontribusi in } \\
& \text { cash dan in kind }\end{array}$ & $\begin{array}{ll}\text { - } & \text { Sesuai desain } \\
\text { - } & \text { Sistem } \\
\text { gotongroyong } \\
\text { dengan konversi } \\
\text { jika masyarakat } \\
\text { berhalangan ikut } \\
\text { - } & \text { Adanya strategi } \\
\text { mendorong } \\
\text { partisipasi } \\
\text { masyarakat }\end{array}$ \\
\hline 4. & $\begin{array}{l}\text { Keikutsertaan } \\
\text { sesuai gender } \\
\text { dan status } \\
\text { sosial }\end{array}$ & $\begin{array}{l}\text { - } \text { Menekankan } \\
\text { partisipasi } \\
\text { masyarakat } \\
\text { miskin dan } \\
\text { perempuan } \\
\text { dalam seluruh } \\
\text { tahapan proyek }\end{array}$ & 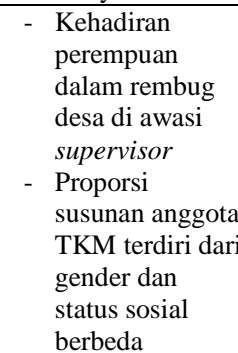 \\
\hline 5. & $\begin{array}{l}\text { Investasi } \\
\text { pengembanga } \\
\text { n kapasitas } \\
\text { CBO }\end{array}$ & 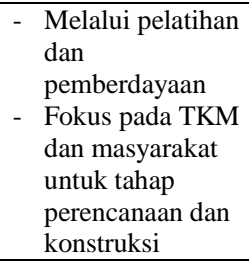 & $\begin{array}{ll}\text { - } & \text { Pelatihan dan } \\
\text { pemberdayaan } \\
\text { masyarakat }\end{array}$ \\
\hline 6. & $\begin{array}{l}\text { Fasilitas } \\
\text { informasi } \\
\text { untuk } \\
\text { komunitas }\end{array}$ & $\begin{array}{l}\text { - } \text { TKKc sebagai } \\
\text { fasilitator } \\
\text { informasi } \\
\text { - Road show } \\
\text { - Papan informasi }\end{array}$ & $\begin{array}{ll}\text { - } & \text { Menerima } \\
& \text { informasi dari } \\
& \text { TKKc } \\
\text { - } & \text { Road show } \\
\text { - } & \text { TKM } \\
& \text { menyediakan } \\
& \text { papan-papan } \\
& \text { informasi } \\
\end{array}$ \\
\hline 7. & $\begin{array}{l}\text { Aturan } \\
\text { sederhana } \\
\text { dan insentif } \\
\text { kuat }\end{array}$ & $\begin{array}{l}\text { - Mensyaratkan } \\
\text { adanya tunjangan } \\
\text { untuk } \\
\text { TKM/UPS, } \\
\text { terutama untuk } \\
\text { tugas-tugas } \\
\text { spesifik }\end{array}$ & $\begin{array}{l}\text { TKM dan UPS } \\
\text { mendapatkan } \\
\text { insentif/tunjangan }\end{array}$ \\
\hline 8. & $\begin{array}{l}\text { Desain kerja } \\
\text { fleksibel }\end{array}$ & $\begin{array}{l}\text { - Adanya pilihan } \\
\text { komponen } \\
\text { kegiatan }\end{array}$ & $\begin{array}{l}\text { Pemilihan } \\
\text { komponen kegiatan } \\
\text { sesuai potensi yang }\end{array}$ \\
\hline
\end{tabular}

\begin{tabular}{|c|c|c|c|}
\hline & & $\begin{array}{l}\text { - Pelaksanaan } \\
\text { diserhakan } \\
\text { kepada } \\
\text { masyarakat } \\
\text { sesuai kebutuhan }\end{array}$ & dimiliki \\
\hline 9. & Scaling up & $\begin{array}{l}\text { Menjadi } \\
\text { tanggungjawab } \\
\text { UPS }\end{array}$ & $\begin{array}{l}\text { Sebatas pada } \\
\text { pengelolaan iuran }\end{array}$ \\
\hline $\begin{array}{l}1 \\
0 .\end{array}$ & Exit strategy & 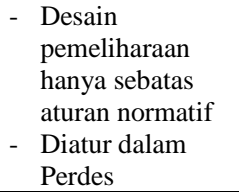 & $\begin{array}{l}\text { UPS sebagai } \\
\text { organisasi } \\
\text { pemeliharaan belum } \\
\text { memiliki struktur } \\
\text { yang kokoh dan } \\
\text { mandiri }\end{array}$ \\
\hline
\end{tabular}

\section{Efektivitas Proyek WSLIC-2 dalam Menghasilkan} Manfaat yang Diharapkan

Efektivitas mengukur sejauh mana pencapian hasil keluaran, manfaat, dan dampak proyek. Berdasarkan hasil capaian keluaran, manfaat, dan dampak proyek WSLIC-2, dari segi penyediaan sarana air bersih dan manajemen kegiatan, proyek WSLIC-2 dinilai sudah cukup efektif. Sebagian masyarakat kini dapat dengan mudah mendapatkan air bersih dari sarana air bersih WSLIC-2. Keefektivan tersebut didukung pula oleh kesanggupan masyarakat untuk membayar biaya pemasangan dan iuran rutin. Sebagian besar, yakni sebanyak 52 persen responden merupakan pengguna sarana air bersih WSLIC-2 berjenis sambungan rumah (SR). Jumlah pengguna SR pun semakin meningkat. Data awal pengguna SR berjumlah 326 rumah, kemudian meningkat menjadi 363 rumah tangga. Adapun untuk pengguna keran umum (KU) WSLIC-2 hanya sebesar 24 persen. Sisanya, sebesar 24 persen adalah mereka yang tidak ikut menikmati sarana air bersih WSLIC-2.

Berdasarkan segi upaya peningkatan derajat kesehatan melalui peningkatan akses masyarakat terhadap sanitasi, dinilai masih belum optimal dijalankan. Sehingga hasil yang diharapkan belum tercapai dengan maksimal. Hal tersebut dilihat berdasarkan capaian hasil komponenkomponen proyek WSLIC-2 yang berhubungan dengan sanitasi sehat.

Secara statistik, perubahan sikap, perasaan, keinginan, dan tindakan yang menunjukkan perilaku hidup bersih pada masyarakat belum seluruhnya signifikan. Perilaku hidup bersih masyarakat tidak berubah secara signifikan. Namun, berdasarkan hasil pengukuran perubahan tersebut tidak muncul karena masyarakat telah memiliki kebiasaan berperilaku hidup bersih baik sebelum dan setelah pelaksanaan proyek WSLIC-2.

Kegiatan CLTS yang dilakukan belum berhasil memicu perubahan masyarakat mengenai perilaku sanitasi sehat dari negatif menjadi positif. Beberapa masyarakat masih merasa jijik, malu, dan tidak berdosa, ketika BAB di sungai. Namun, masyarakat mengaku bingung dan terpaksa $B A B$ di sungai karena tidak memiliki jamban dan untuk membuat jamban sendiri pun mengaku belum mampu. Kegiatan CLTS sudah mampu memicu perasaan masyarakat mengenai perilaku sanitasi sehat namun belum berhasil memfasilitasi masyarakat untuk menyusun rencana tindak lanjut masyarakat agar terbebas dari perilaku BAB di sungai. 
Pada tingkat manfaat proyek, jumlah kepemilikan jamban sebagai sarana perilaku sanitasi sehat dan menjadi tujuan akhir kegiatan CLTS tersebut belum meningkat secara signifikan. Meskipun secara statistik, kebiasaan masyarakat mengenai perilaku $\mathrm{BAB}$ di jamban meningkat secara signifikan. Hal tersebut dikarenakan adanya sarana sanitasi sebagi hasil dari proyek Program Nasional Pemberdayaan Masyarakat (PNPM) Mandiri yang bergerak di bidang pembangunan jamban umum ketika proyek WSLIC-2 berjalan.

Kondisi sarana sanitasi untuk siswa SD pun menurun drastis. Sarana fisik sanitasi berupa jamban sekolah tidak terpelihara dengan baik. Jamban sekolah yang terbangun semula berjumlah enam unit, namun yang masih berfungsi hanya satu unit. Satu unit jamban sekolah yang masih berfungsi tersebut berada di SD 4 Desa Pangradin yang lokasinya berjarak jauh dari pemukiman penduduk dan juga aliran sungai sehingga jamban tersebut menjadi satu-satunya tempat BAB siswa SD 4. Berdasarkan alasan itulah tingkat akses sanitasi siswa SD secara statistik meningkat signifikan. Sama halnya dengan sarana mencuci tangan sekolah, kondisinya menurun drastis. Berdasarkan hasil wawancara, dari 15 unit sarana mencuci tangan yang dibuat, hampir tidak ada lagi sarana mencuci tangan yang berfungsi akibat tidak adanya pemeliharaan yang baik.

Dilihat dari segi manajemen proyek WSLIC-2, pelakasanaan proyek WSLIC-2 sudah berhasil mendorong partisipasi masyarakat pada tahap perencanaan dan teknis pembangunan melalui aturan main yang sudah ditetapkan. Partisipasi masyarakat pada tahap perencanaan dan teknis pembangunan sudah cukup tinggi. Sedangkan pada tahap pemeliharaan, tingkat partisipasi masyarakat masih sangat rendah. Hal ini disebabkan tugas pemeliharaan (termasuk pengelolaan) dibebankan kepada UPS. Namun, UPS pun ternyata belum mampu menjalankan tugas dan fungsinya secara optimal. Dibentuknya UPS sebagai organiasis operasi dan pemeliharaan sarana air bersih dan sanitasi WSLIC-2 tidak disertai dengan adanya upaya pengkohan organisasi tersebut. UPS berjalan sebatas pada penagihan iuran air bersih WSLIC-2 dan perbaikan kebocoran pipa saja. UPS seharusnya mampu melakukan pengembangan program dan menjangaku seluruh lapisan masyarakat untuk dapat mengakses air bersih dengan pengelolaan yang lebih bersifat kooperatif.

Berdasarkan capaian hasil komponen dampak, status kesehatan masyarakat dan produktivitas belum terukur berubah secara signifikan. Namun, tingkat penyakit gata-gatal pada siswa SD menurun secara signifikan. Upaya peningkatan derajat kesehatan masyarakat melalui adanya proyek WSLIC-2 di Desa Pangradin bukan merupakan upaya penurunan angka penyakit tertentu, namun lebih bersifat kepada pencegahan penyakit karena masih banyak perilaku masyarakat yang BAB di jamban dan menggunakan air sungai sebagai sumber pemenuhan kebutuhan air. Sehingga secara statistik dapat dikatakan bahwa tingkat status kesehatan masyarakat belum berubah seacara signifikan.
Meskipun demikian, jumlah masyarakat Desa Pangradin yang menderita penyakit akibat masalah lingkungan jauh lebih rendah daripada Desa lain. Produktivitas masyarakat yang diukur berdasarkan tingkat intensitas absen dalam kegiatan bekerja dan sekolah belum menunjukan hasil yang signifikan pula. Rata-rata hanya 15 persen responden yang mengaku sering bolos bekerja/sekolah dengan alasan sakit, dan sakit yang menyebabkan masyarakat harus bolos bekerja/sekolah pun bukan sakit yang disebabkan oleh masalah perilaku hidup bersih dan sanitasi yang masih rendah.

Variabel dampak proyek WSLIC-2 yang diharapkan lainnya adalah peningkatan kualitas hidup masyarakat. Kualitas hidup tersebut diukur menggunakan dua variabel turunan, yaitu kualitas kesehatan dan kualitas kesejahteraan yang diukur berdasarkan 10 level status kesehatan dan kesejahteraan menurut subyektivitas responden. Hasil uji statistik pada pengkuran status kesehatan dan kesejahteraan tersebut, terdapat peningkatan status yang sudah signifikan, baik status kesehatan maupun status kesejahteraan. Beberapa responden mengaku merasa nyaman dan terntram dengan adanya air bersih WSLIC-2. Rasa capek masyarakat berkurang karena tidak harus mengeluarkan energi besar untuk bisa mendapatkan air bersih

Variabel lain yang digunkan untuk mengukur kualitas hidup masyarakat adalah perubahan pendapatan. Namun secara statistik pendapatan masyarakat yang diukur berdasarkan jumlah pengeluaran belum meningkat secara signifikan sesudah adanya proyek WSLIC-2 untuk rumahtangga mampu namun cukup signifikan untuk rumahtangga tidak mampu. Berikut disajikan secara ringkas pencapaian hasil proyek WSLIC-2 di Desa Pangradin pada Tabel 3.

Tabel 3. Ringkasan Capaian Hasil Keluaran, Manfaat, dan Dampak Proyek WSLIC-2

\begin{tabular}{|c|c|}
\hline Variabel & Hasil \\
\hline \multicolumn{2}{|l|}{ Keluaran } \\
\hline \multirow{2}{*}{\multicolumn{2}{|c|}{$\begin{array}{l}\text { A. Kecenderungan Perubahan Perilaku } \\
\text { Hidup Bersih dan Sehat }\end{array}$}} \\
\hline & \\
\hline $\begin{array}{l}\text { 1. Sikap masyarakat mengenai perilaku } \\
\text { sanitasi sehat }\end{array}$ & $\begin{array}{l}\text { Berubah } \\
\text { sebagian }\end{array}$ \\
\hline 2. Sikap masyarakat mengenai PHBS & $\begin{array}{c}\text { Tidak } \\
\text { berubah }\end{array}$ \\
\hline $\begin{array}{l}\text { 3. Perasaan masyarakat mengenai } \mathrm{BAB} \\
\text { di sungai }\end{array}$ & $\begin{array}{l}\text { Sebagian } \\
\text { besar } \\
\text { berubah }\end{array}$ \\
\hline $\begin{array}{l}\text { 4. Keinginan masyarakat untuk BAB di } \\
\text { jamban dan memilki jamban sendiri }\end{array}$ & $\begin{array}{c}\text { Tidak } \\
\text { berubah }\end{array}$ \\
\hline \multicolumn{2}{|l|}{ B. Pengembangan Kapasitas Masyarakat } \\
\hline 1. Kemampuan dalam kegiatan CLTS & $\begin{array}{l}\text { Belum } \\
\text { sepenuhnya } \\
\text { mampu }\end{array}$ \\
\hline 2. Kemampuan dalam kegiatan PHBS & Mampu \\
\hline $\begin{array}{l}\text { 3. Kemampuan dalam pengelolaan dan } \\
\text { pemeliharaan }\end{array}$ & Mampu \\
\hline \multicolumn{2}{|l|}{$\begin{array}{l}\text { C. Penyediaan Sarana Air Bersih dan } \\
\text { Sanitasi }\end{array}$} \\
\hline 1. Sarana air bersih & $\begin{array}{l}\text { Pipa } \\
\text { gravitasi }\end{array}$ \\
\hline $\begin{array}{l}\text { 2. Sarana sanitasi } \\
\text { a. Jamban keluaraga } \\
\text { bergulir) }\end{array}$ & Tidak ada \\
\hline
\end{tabular}




\section{b. Jamban sekolah}

c. Jamban kantor desa dan puskesmas

D. Adanya Manajeman Kegiatan

1. Manajemen Proyek

2. Manajemen Pengelolaan

3. Perhitungan Tarif Iurana

Manfaat

A. Perbaikan perilaku hidup bersih dan sehat

1. Perilaku hidup bersih

2. Perilaku sanitasi sehat masyarakat

3. Perilaku hidup bersih siswa SD

4. Peningkatan kepemilikan jamban sendiri

B. Kesinambungan pemberdayaan masyarakat secara partisipatif

1. Kegiatan perencanaan

2. Kegiatan teknis konstruksi

3. Kegiatan pemeliharaan

C. Peningkatan pelayanan kesehatan masyarakat

1. Akses terhadap air bersih

2. Akses terhadap sanitasi

3. Akses terhadap sanitasi sekolah

D. Pemeliharaan sarana air bersih dan sanitasi

1. Jumlah sarana air bersih

2. Jumlah sarana sanitasi

3. Jumlah sarana cuci tangan

\section{Dampak}

A. Mutu Kesehatan

Intensitas penderita penyakit yang disebabkan oleh air bersih dan sanitasi yang tidak memadai

B. Produktivitas

Intensitas ketidakhadiran dalam Tidak bekerja/sekolah berubah

C. Kualitas Hidup

1. Kualitas kesehatan

2. Kualitas kesejahteraan

3. Perubahan pendapatan

Meningkat

Meningkat

Berubah

*) Penulis menyimpulkan peningkatan perilaku sanitasi sehat dan akses sanitasi masyarakat bukan sebagai hasil dari proyek WSLIC-2, akan tetapi akibat adanya PNPM Mandiri.

\section{Relevansi Keluaran Proyek WSLIC-2 dalam Menghasilkan Dampak yang Diharapakan}

Relevenasi diartikan sejauh mana program atau proyek menempatkan masalah pada prioritas utama terutama dilihat dari sudut pandang penerima proyek. Secara desain proyek WSLIC-2 telah memfokuskan diri pada prinsip-prinsip relevansi tersebut yaitu dengan adanya kriteria pemilihan lokasi proyek, prinsip fleksibilitas melalui adanya pilihan kegiatan, dan pernyataan minat dari masyarakat sehingga sehingga proyek WSLIC-2 sangat dimungkinkan menjadi proyek yang relevan untuk pemanfaatnya (beneficiaries). Masyarakat Desa Pangradin memiliki sumber mata air yang melimpah namun pada kesehariannya mayoritas masyarakat menggunakan air sungai untuk keperluan mencuci, mandi, bahkan BAB. Proyek WSLIC-2 dipahami oleh TKM sebagai proyek yang bertujuan untuk mendekatkan air tersebut kepada masyarakat.
Secara statistika, tingkat kesulitan air pada masyarakat menurun secara signifikan, dalam arti cukup banyak responden (43 persen) yang semula kesulitan air menjadi tidak sulit lagi setelah adanya sarana air bersih proyek WSLIC-2. Beberapa responden mengaku mengalami kesulitan sebelum adanya proyek WSLIC-2 dan tidak kesulitan lagi sesudah pelaksanaan proyek WSLIC-2. Namun, sebanyak 13 responden (11 responden diantaranya adalah rumahtangga tidak mampu) masih tetap merasa kesulitan air meskipun telah ada sarana air bersih WSLIC-2. Responden yang masih kesulitan air tersebut umumnya mereka yang tidak mampu untuk memasang sambungan rumah air bersih WSLIC-2, namun untuk menuju keran umum pun jaraknya jauh dari tempat tinggal mereka sehingga lebih memilih pergi ke sungai.

Persentase terbesar untuk perubahan kesulitan air antara sebelum dan sesudah pelaksanaan proyek WSLIC-2 adalah 46 persen, yaitu menyatakan bahwa mereka tidak kesulitan air baik sebelum maupun setelah adanya sarana air bersih WSLIC-2. Namun, sebagian diantara mereka tetap memanfaatkan sarana air bersih WSLIC-2 dan menutup sumur-sumur gali yang semula mereka gunakan sebagai sumber air bersih. Rata-rata 68 persen responden beralih menggunakan sarana air bersih WSLIC-2, baik yang kesulitan air maupun yang tidak kesulitan air sebelum adanya proyek WSLIC-2. Sebagian responden yang menolak menggunakan sarana air bersih WSLIC-2 mengaku karena lokasi rumah mereka cukup dekat dengan sumber mata air dan lebih memilih membuat sambungan sendiri ke rumah-rumah mereka. Dan sebagian lagi, sebagaimana dijelaskan di atas mengaku tidak ikut menikmati hasil proyek karena tidak mampu membayar biaya pemasangan sementara untuk menuju keran umum pun lokasinya jauh dari rumah mereka sehingga lebih memilih pergi ke sungai yang lebih dekat. Berdasarkan segi penyediaan air bersih, proyek WSLIC-2 sudah dapat dikatakan berhasil dan cukup relevan dengan kebutuhan masyarakat meski pun belum sepenuhnya menjangkau semua masyarakat.

Tujuan akhir sebenarnya proyek WSLIC-2 adalah meningkatkan derajat kesehatan masyarakat. Upaya peningkatan derajat kesehatan tersebut selain diwujudkan melalui peningkatan akses terhadap air bersih dan sanitasi seharusnya diikuti pula dengan perubahan perilaku masyarakat menuju hidup bersih dan sehat. Kegiatan PHBS dan CLTS pada khususnya merupakan kegiatan yang memicu masyarakat untuk berperilaku hidup bersih dan sanitasi sehat, terutama membebaskan masyarakat dari perilaku BAB di sembarang tempat. Meskipun kegiatan CLTS memiliki salah satu prinsip tidak mempromosikan jamban, namun orientasi keberhasilan kegiatan CLTS ini adalah kepemilikan jamban sendiri pada rumah masing-masing sebagai sarana memenuhi kebutuhan perilaku sanitasi sehat.

Secara statistika, perubahan jumlah kepemilikan jamban sendiri pada rumah tangga masyarakat Desa Pangradin belum signifikan. Sebagian responden mengaku belum memilki jamban sendiri dengan alasan terkendala masalah ekonomi. Meski jumlah kepemilikan jamban 
sendiri pada rumah tangga masyarakat tidak meningkat secara signifikan, namun kebiasaan $\mathrm{BAB}$ di jamban pada masyarakat dan siswa SD sudah meningkat secara signifikan. Hal ini disebabkan hadirnya program WSLIC-2 bersamaan dengan hadirnya Program Nasional Pemberdayaan Masyarakat (PNPM) Mandiri yang secara kebetulan bergerak di bidang pembangunan jamban umum. Sarana sanitasi yang dibangun dari proyek WSLIC-2 hanyalah jamban sekolah sehingga membuat akses siswa SD terhadap sanitasi meningkat.

Secara konsep, kegiatan CLTS memiliki prinsip tidak menggurui, tidak memaksa, dan tidak mempromosikan jamban serta tidak menentukan indikator keberhasilan dengan menghitung jamban, akan tetapi menentukan indikator keberhasilan berdasarkan perhitungan tidak ada lagi masyarakat yang BAB sembarangan. Prinsip lainnya yang paling penting adalah prinsip pemberdayaan dan menjadikan masyarakat sebagai pemimpin dan agen penyeru tindakan sanitasi sehat. Kegiatan CLTS pun memiliki tahapan kegiatan yang cukup panjang dan intensif. Tahapan kegiatan tersebut mulai dari bina suasana, kegiatan pemicuan dengan berbagai pilihan metode (Transek, pemetaan, oral fecal, demonstrasi), fasilitasi untuk tindak lanjut masyarakat, dan terkahir adalah monitoring. Strategi teknis pelaksanaan CLTS berdasarkan lokasi dan waktu sudah cukup relevan dengan menyesuaikan terhadap kondisi masyarakat. Lokasi dan waktu kegiatan dipilih pada lokasi dan waktu di mana masyarakat sering berkumpul terutama di waktu sore dan pagi menjelang jam makan siang. Namun, kegiatan CLTS di Desa Pangradin tidak dilakukan secara tuntas, akan tetapi sebatas sampai pada pemicuan saja dan tidak dilanjutkan pada tahap fasilitasi untuk tindak lanjut dan montoring yang berkesinambungan. Hal ini menyebabkan kegiatan CLTS dipahami masyarakat sebagai kegiatan yang hanya bertujuan menyuruh masyarakat membuat jamban sendiri di rumah masing-masing, bukan untuk keluar dari kebiasaan BAB sembarangan yang dapat membahayakan kesehatan tersebut.

Hadirnya kegiatan CLTS merupakan pengganti dari kegiatan jamban bergulir yang seharusnya dilaksanakan pada proyek WSLIC-2. Kegiatan CLTS dilakukan bukan untuk memberikan solusi kepada masyarakat dan subsidi sarana fisik akan tetapi masyarakat terpicu kebutuhannya untuk meninggalkan kebiasaan BAB disembarang tempat dan menghasilkan solusi sendiri untuk keluar dari kebiasaan tersebut. Akan lebih relevan jika kegiatan CLTS ini dilakukan lebih intensif bersama masyarakat sasaran, termasuk memfasilitasi masyarakat membahas rencana tindak lanjut masyarakat untuk sampai pada solusi akhir bebas BAB sembarangan. Berdasarkan hasil pengkuran di lapangan sebagian besar (62 persen) responden menyatakan setuju bahwa BAB di sungai dapat menyebabkan pencemaran dan penyakit, akan tetapi meraka pun menyatakan bingung untuk keluar dari kebiasaan BAB di sungai karena untuk bisa memiliki jamban sendiri mereka merasa belum sanggup membuatnya. Meskipun masih ada beberapa responden yang mengaku merasa lebih nyaman $\mathrm{BAB}$ di sungai dari pada di jamban. Kegiatan CLTS yang lebih intensif ternyata masih diperlukan tak hanya untuk masyarakat yang sudah terbangun kebutuhannya untuk BAB di jamban akan tetapi pula untuk masyarakat yang masih belum terpicu.

Pada akhirnya, keluaran proyek WSLIC-2 yaitu sarana fisik yang dihasilkan (sarana air bersih dan sanitasi) yang sesuai dengan kebutuhan masyarakat dan memberikan manfaat yang besar untuk masyarakat terlebih jika disertai dengan peningkatan perilaku hidup bersih dan sanitasi sehat pada masyarakat melalui kegiatan CLTS dan PHBS yang intensif dijalankanakan relevan menghasilkan dampak yang diharapkan proyek WSLIC-2, yaitu meningkatkan derajat kesehatan masyarakat.

\section{Keberlanjutan Dampak Proyek WSLIC-2}

Dampak proyek yang diharapkan, yaitu meningkatnya derajat kesehatan masyarakat mulai terlihat. Sementara itu, kegiatan CLTS yang dilaksanakan belum mampu merubah sikap dan perilaku hidup bersih dan sehat pada masyarakat, terutama sikap dan perilaku sanitasi sehat. Hal tersebut menunjukkan bahwa tanpa didukung dengan perubahan perilaku hidup bersih dan sanitasi sehat masyarakat, hasil proyek sudah mengarah pada adanya peningkatan derajat kesehatan masarakat sebagai dampak yang diharapkan dari pelaksanaan proyek.

Sebagaimana hasil pembahasan di atas, proyek WSLIC2 sudah efektif dalam menyediakan layanan sarana air bersih WSLIC-2 dan menghasilkan manfaat yang besar untuk masyarakat. Dampak yang diharapkan pun sudah mengarah kepada adanya peningkatan derajat kesehatan masyarakat -meskipun tanpa didukung adanya perubahan perilaku hidup bersih dan sehat masyarakat-. Sehingga korelasi yang dapat dilihat adalah sarana air bersih WSLIC-2 menjadi faktor penting dalam upaya mewujudkan peningkatan derajat kesehatan masyarakat yang diharapkan dalam pelaksanaan proyek ini. Oleh karena itu, terpeliharanya sarana air bersih pun menjadi penting agar proyek dapat berkelanjutan. Ironisnya, kondisi UPS sebagai organisasi yang memegang peranan sentral dalam pemeliharaan ternyata belum memiliki struktur yang kokoh. Maka terpeliharanya sarana air bersih WSLIC-2 belum dapat dipastikan hingga jangka waktu ke depan sehingga proyek WSLIC-2 belum terjamin keberlanjutannya.

Secara konsep dan temuan di lapangan, terlihat bahwa proyek WSLIC-2 belum mengarah kepada adanya upaya mewujudkan keberlanjutan proyek. Desain scaling up dan exit strategi sebagai konsep yang berkaitan dengan pemeliharaan belum termuat secara jelas dalam desain proyek WSLIC-2. Bagaimana partisipasi masyarakat berdasarkan status sosial dan gender pada fase pemeliharaan pun tidak tertuang dalam desain proyek. Begitu pula dengan akses informasi pasca proyek, terutama mengenai akuntabilitas dana pemeliharaan proyek yang tidak transparan -hal ini bahkan telah berpotensi memicu adanya konflik pada masyarakat- telah menimbulkan ketidakpercayaan masyarakat terhadap UPS sehingga membuat UPS kehilangan kepercayaan diri dalam menjalankan tugasnya. 
Pada berbagai hasil evaluasi lembaga-lembaga terkait menyatakan proyek WSLIC-2 se-Indonesia secara keseluruhan belum menjamin adanya keberlanjutan. Dasar hukum organisasi operasi dan pemeliharaan proyek WSLIC-2 dinilai masih lemah sehingga sulit melakukan kerjasama dengan pihak lain (LP3ES 2006). Selain itu proyek WSLIC-2 juga dinilai memiliki masalah keberlanjutan karena rendahnya kapasitas kelompok pemeliharaan atau tidak jelasnya strategi perampungan/keberlanjutan proyek (Asian Development Bank 2008). Hal tersebut nampaknya juga terjadi pada pelaksanaan proyek WSLIC-2 di Desa Pangradin. UPS belum memiliki dukungan kebijakan dalam melakukan pengembangan program dan bekerjasama dengan pihak lain -bahkan cenderung tidak dipercaya masyarakat-. Selain itu peningkatan kapasitas masyarakat hanya berfokus pada TKM dan sebagian besar anggota TKM yang memiliki kapasitas yang relatif baik tidak terlibat lagi dalam kegiatan pemeliharaan dan struktur UPS. Kapasitas anggota UPS dinilai masih lemah, bahkan untuk masalah pengelolaan administrasi pemeliharan proyek sekalipun.

\section{KESIMPULAN DAN SARAN}

\section{Kesimpulan}

Berdasarkan pada hasil analisis dokumen WSLIC-2 serta dengan melihat implementasi proyek di lapangan, desain proyek WSLIC-2 yang dirancang sudah mendekati konsep pemberdayaan berdasarkan 10 prinsip CDD pada fase konstruksi, namun belum mengakar kuat pada fase pemeliharaan proyek. Hasil pengukuran terhadap pencapaian keluaran, manfaat, dan dampak proyek menunjukkan bahwa proyek cukup efektif dalam meningkatkan akses masyarakat terhadap air bersih, namun dalam aspek sanitasi, yakni membebaskan masyarakat dari perilaku BAB (Buang Air Besar) di sembarang tempat, proyek WSLIC-2 dinilai masih belum efektif. Sehingga proyek WSLIC-2 di Desa Pangradin dinilai belum sepenuhnya efektif dalam menghasilkan manfaat yang diharapkan. Berdasarkan tingkat kebutuhan dan tingkat pemanfaatan masyarakat terhadap keluaran proyek yang dihasilkan, proyek WSLIC-2 cukup relevan, namun belum menjamin adanya keberlanjutan dampak yang diharapkan proyek WSLIC-2.

Pendekatan pembangunan dengan berbasis pada pemberdayaan masyarakat pun telah diakui dapat membawa pada pembangunan berkelanjutan. Pada kenyataannya, konsep CDD hanya menekankan pemberdayaan masyarakat pada fase perencanaan dan konstruksi proyek. Masyarakat difasilitasi dan ditingkatkan kapasitasnya dalam rangka menyukseskan proyek pada kedua fase ini. Pada desain proyek, rancangan mengenai pengembangan kapasitas untuk kedua fase ini juga dijelaskan dengan sangat rinci, sementara rancangan untuk fase pemeliharaan hanya sebatas aturan normatif meskipun secara tersurat desain pemeliharaan pasca proyek termuat dalam konsep CDD melalui prinsip scaling up dan exit strategy.
Pendekatan pembangunan dengan model pemberdayaan saja tidak cukup untuk membawa pada pembangunan berkelanjutan jika tidak disertai dengan upaya perumusan proyek pada fase pemeliharaan. Upaya tersebut dapat dilakukan dengan merumuskan suatu desain kelembagaan pemeliharaan yang ajeg.

\section{Saran}

Saran yang dapat diberikan berdasarkan hasil penelitian ini adalah:

\section{Perbaikan kegiatan CLTS dengan lebih intensif}

\section{Peningkatan kapasitas tim CLTS}

3. Penguatan kelembagaan pemeliharaan melalui pengokohan struktur UPS dan peningkatan partisipasi masyarakat dalam pemeliharaan hasil proyek.

\section{DAFTAR PUSTAKA}

Adi, Isbandi Rukminto 2003. Pemberdayaan, Pengembangan Masyarakat dan Intervensi Komunitas: Pengantar pada Pemikiran dan Pendekatan Praktis. Edisi Revisi. Lembaga Penerbit Fakultas Ekonomi Universitas Indonesia. Jakarta.

Agusta, Ivanovich 2002. Metode Evaluasi Program Pemberdayaan. Konggres dan Seminar IV Ikatan Sosiologi Indonesia. Bogor. 28-29 Agustus 2002.

Anonim 2006. Kajian Cepat Terhadap Programprogram Pengentasan Kemiskinan Pemerintah Indonesia : WSLIC-2 dan PAMSIMAS. LP3ES. http://www.pnpmmandiri.org/ elibrary/files/disk1/1/pnpm--lp3es-10-1-lp3es_fia.pdf diakses pada tanggal 10 Oktober 2009

Asian Development Bank 2008. Hasil Review dan Evaluasi atas Program-program yang Berpihak pada Rakyat Miskin di Indonesia. Hickling. Jakarta.

Badan Pusat Statistik 2009. Perkembangan Beberapa Indikator Utama Sosial-Ekonomi Indonesia.

http://www.bps.go.id/download_file/booklet_leaf let/ booklet_okt2009.pdf diakses pada 10 Februari 2010

Dale, Reidar 2001. Evaluation Framework for Development Program and Project. Sage Publication. New Delhi.

Departemen Kesehatan 2003a. Proyek Air Bersih dan Sanitasi Untuk Masyarakat Berpenghasilan Rendah-II, Pinjaman Bank Dunia THN 20002005 : Petunjuk Pelaksanaan Manajemen Proyek. Direktorat Jenderal Pemberantasan Penyakit Menular dan Penyehatan Lingkungan.

2003b. Proyek Air Bersih dan Sanitasi Untuk Masyarakat Berpenghasilan Rendah-II, Pinjaman Bank Dunia THN 2000-2005 : Petunjuk Pelaksanaan Operasional Tingkat Desa. 
Direktorat Jenderal Pemberantasan Penyakit Menular dan Penyehatan Lingkungan.

2008. Strategi Nasional Sanitasi Total Berbasis Masyarakat. http://www.depkes.go.id/downloads/ pedoman_stbm.pdf diakses pada tanggal 24 November 2009

Departemen Pertanian 1990. Sistem Monitoring dan Evaluasi Proyek-proyek Pembangunan dan Pedesaan. Balai Pendidikan dan Penyuluhan Pertanian.

Dongier, P, JV Domelen, E Ostrom, A Ryan, W Wakeman, A Bebbington, S Alkire, T Esmail, M Polski 2003. Community-Driven Development. World Bank. Washington DC. http://siteresources.worldbank.org/INTPRS1 /Resources/3836061205334112622/5805chap9.p df diakses pada tanggal 24 Desember 2009

Hans P. Binswanger-Mkhize, Jacomina P. de Regt, dan Stephen Spector 2009. Scaling Up Local \& Community Driven Development (LCDD) : A Real World Guide to Its Theory and Practice. World Bank.

Hasan, Iqbal 2002. Pokok-pokok Materi Metodologi Penelitian dan Aplikasinya. Ghalia Indonesia. Jakarta.

Operations Evaluation Department. 2003. CommunityDriven Development: A Study Methodology. World Bank. Washington.

http://siteresources.worldbank.org/EXTEFFWBS UPCOMDRIDEV/Resources/discussion_paper.p df diakses pada tanggal 30 Desember 2009

Prasetyo, Bambang \& Lina Miftahul Jannah 2006. Metode Penelitian Kuantitaif: Teori dan Aplikasi. PT Raja Grafindo Persada. Jakarta.

Sekretariat Balai Desa Pangradin 2008. Rencana Kerja Masyarakat : Program Sarana Air Bersih dan Sanitasi, Water Sanitation for Low Income Communities (WSLIC-2). TKM Curug Bandung Desa Pangradin.

Siegel, Sidney 1997. Statistik Nonparametrik Untuk Ilmu-ilmu Sosial. Jakarta. PT Gramedia.

Singarimbun, M. \& Effendi, S. 1989. Metode Penelitian Survai. Jakarta. LP3ES.

Subanu, Leksono Probo \& Vyta Elysia 2008. "Partisipasi Masyarakat Di Indonesia: Pandangan Dari Sebuah Jendela Akademik." dalam Seminar Nasional Keberlanjutan Partisipasi Masyarakat Dalam Pembangunan. Yogyakarta. 25-26 Juli 2008.

Sutomo, Harry Hikmat, \& Tumpal P. Saragi 2002. Modul pelatihan dan Pedoman Praktis Perencanaan Partisipatif. Jakarta. CV Cipruy.

Tohjiwa, Agus Dharma \& Agus Suparman 2008. "Perubahan Sosial Pada Pemberdayaan Komunitas Dalam Penyediaan Prasarana Fisik".
Seminar Nasional Keberlanjutan Partisipasi Masyarakat Dalam Pembangunan, Yogyakarta, 25-26 Juli 2008.

Uphoff, Norman. 1986. "Local Institutional Development for Rural Infrastructure." dalam Local Institutional Development: An Analytical Sourcebook with Cases. New York. Kumarian Press. 